\title{
Discouraging Employee Turnover through a Coaching Optimization Program
}

\author{
Nurhayati F. M. Nofitri ${ }^{\mathrm{a}}$ and Alice Salendu ${ }^{\mathrm{b} *}$ \\ ${ }^{a}$ Faculty of Psychology, Universitas Indonesia, Depok, Indonesia; ${ }^{b}$ Department of Industrial and \\ Organizational Psychology, Faculty of Psychology, Universitas Indonesia, Depok, Indonesia \\ *Corresponding author: \\ Alice Salendu \\ Industrial and Organizational Psychology Department \\ Faculty of Psychology, Universitas Indonesia \\ Jl. Lkr. Kampus Raya, Depok, Jawa Barat \\ Indonesia, 16424 \\ Tel.: +62 217270004 \\ Email: alice.salendu@gmail.com
}




\title{
Discouraging employee turnover through a coaching optimization program
}

\begin{abstract}
PT $\mathrm{X}$ is one of the rapidly growing Business Process Outsource (BPO) companies in Indonesia that is constantly challenged by employe turnover issues. The focus of this research is to determine and implement an appropriate intervention program in order to cope with the employe turnover problem at PT X. Initial qualitative data indicated a problem with perceived organizational support (POS) as a possible cause of turnover intention (TI) at PT X. In order to substantiate this, quantitative data for TI and POS were collected using an adaptation of a TI questionnaire used by Lindblom, Kajalo, and Mitronen (2015) and an adaptation of a POS survey used in Neves and Eisenberger (2014). The measurement of data from 164 respondents revealed a significant negative relationship between POS and TI $(r=-.52, p=.00)$. Further analysis was made to design an intervention, resulting in a four-stage coaching optimization program. The first stage equips the participants with knowledge and understanding of solution-focus (SF) coaching, the second stage allows room for the implementation which will be evaluated at the third stage, and the last stage serves as a reinforcement to sustain the SF coaching practice at PT X. The first stage of coaching debriefing was implemented with eight team leaders and supervisory level employes of PT X. It was further evaluated at the learning level, which resulted in a significant increase in participant knowledge compared to before the implementation. This result can be used as a reference in implementing coaching optimization programs as a way of increasing POS to reduce TI.
\end{abstract}

Keywords: coaching, perceived organizational support, turnover intention

\section{Introduction}

A company's needs for effective and efficient employees are increasing along with current rapid developments in information and technology. As a result, a particular business sector known as Business Process Outsource (BPO) has emerged. BPO describes the operation of contracting out a task to another company to perform a certain function on its behalf (Umer \& Naseem, 2011). $\mathrm{BPO}$ has become a common and important means of companies being able to simultaneously maintain their revenue and the quality of their business process (Demirbag, Mellahi, Sahadev, \& Elliston, 2012) because it fulfilling the company's needs of increasing effectiveness and efficiency in a practical way. (Future of Work, 2012). The rapid growth of business in the BPO sector is also occurring in Indonesia, where the BPO service potential is one of the five top strongest in the world (A. T. Kearney, 2016). Indonesia's government views this growing BPO sector as a solution to improving the country's target investments ("BUMN Harus," 2017). Thus, BPO companies in Indonesia are potential sources for improvement in industrial and financial areas of the country.

BPO companies generally focus on one typical area of business processes. In Indonesia, one of the business process areas in which BPO companies prosper is contact centers. Basically, a contact center is an integration of telephone technology and an information system where an agent must perform the act of contacting through a specific operational system that automatically distributes work, decides on the speed of the work, and monitors the agent's performance (Ellis $\&$ Taylor, 2006). The more a company's business and customer base expands, the more complex its requirements for contact center management are, and the more prosperous the BPO contact 
center industry. This increased complexity can be seen by a more than $200 \%$ increase of contact center interaction rates in 2015 (Research and Markets, 2016). This also indicates the growth of Indonesia's BPO business sector that operates in the field of contact centers.

BPO companies, especially those that operate in the field of contact centers, have always faced the same employe-related challenges since the business began to emerge. In fact, up to $66 \%$ of CEOs in Indonesia admitted that employe-related issues have become the main challenge that influences a company's performance (Irfandi, 2013). For BPO companies working in the field of contact centers, the main challenge is employe turnover (Bagnara \& Marti as cited in Jacobs \& Roodt 2011).

Turnover is defined as the termination of an individual's job at a company (Tett \& Meyer, 1993). It is one of the parameters used to indicate an organization's well-being and performance (Johnston \& Spinks, 2013). In contact center BPO companies, employes who deliver services are a company's key assets because they directly determine the client's level of customer satisfaction. BPO companies are responsible for the end result of client outsourced functions (Priambada, Mahata, Maryono, \& Kusumanto, 2008); hence, the client's customer satisfaction is one of the key performance indicators for contact center BPO companies. Thus, employe turnover at contact center BPO companies has an adverse effect on organizational performance (Park \& Shaw, 2013). Based on these ideas, contact center BPO companies must carefully manage their employe turnover issues to continue performing successfully.

PT $\mathrm{X}$ is one of the contact center BPO companies in Indonesia that is vastly improving and is able to compete with other companies in the same industry (Research and Markets, 2016). Since its founding in 2008, the company has received several awards for its contact center quality. Even so, this high quality does not exempt PT X from employe turnover issues. Initial diagnosis through qualitative data collection at PT X revealed that continuing employe turnover is one of their main concerns, especially in the Operational Division. The employe turnover rate in this division causes the most damage for the company because it is one of the indicators by which clients measure PT X's performance. Increased turnover at PT X causes an increase in client spending, decreases company performance, and can even lead to the termination of client contracts. Other damages experienced by PT X parallel those mentioned in previous research on the effects of turnover. These include high financial expenditure (Holtom, Mitchell, Lee, \& Eberly, 2008) for the recruiting, selection, and training process of new employes (Saleh, Nair, \& Harum, 2012); a decreasing level of service quality and employe productivity that may lead to the company's decreased ability to compete effectively in the marketplace (Hwang \& Chang, 2009; Gosh, Satyawadi, Joshi, \& Shadman, 2013). A preliminary survey of TI was conducted on the Operational Division employes to identify the projects that most urgently need intervention. This survey suggested that among all projects in Operational Division, Operational Other Projects (Operational OP) has the highest TI.

Varied research was done to study the antecedents of turnover (Yamazakia \& Petchdee, 2015). Those studies found that the strongest antecedent that consistently influences actual turnover behavior is turnover intention (TI) (Griffeth, Hom, \& Gaertner, 2000; Kaur, Mohindru, \& Pankaj, 2013; Tett \& Meyer, 1993; Yamazakia \& Petchdee, 2015). TI is defined as employe's conscious will to leave an organization (Tett \& Meyer, 1993). Measuring TI might allow a company to predict the possibility of employe turnover and assist in the effort to prevent it or at 
least maintain a lower level (Kaur et al, 2013). The explanation of TI antecedents is influenced by theories of March and Simon (in Joseph, Ng, Koh, \& Ang, 2007), who stated that turnover happens when employes feel that their contributions have exceeded their organizational drive. Based on this explanation, TI could be handled through the management of those organizational drives. This idea is parallel to the principle of reciprocity, in which the employe's perception of the organization's intentions, whether good or bad, determines their attitude toward the organization, whether positive or negative (Levinson, 1965). This principle gave birth to the concept of perceived organizational support (POS), which represents an employe's perception of organizational intention (Eisenberger, Huntington, Hutchison, and Sowa, 1986). Correspondingly, a meta-analytical study by Wong, Wong, and Wong (2015) concluded that POS is one of the main predictors of TI. This is also supported by a number of literature reviews and other studies that support the negative influence of POS on TI (Husain \& Asif, 2012; Kalidass \& Bahron, 2015; Rhoades \& Eisenberger, 2002). Furthermore, the author also conducted a preliminary qualitative data collection that resulted in an indication of problems in employe POS that may affect TI among Operational OP department employes.

POS is defined as the employe belief in the extent to which an organization values their contributions and cares about their well-being (Eisenberger et al., 1986). The concept of POS emerged from the organizational support theory that states that to meet socio-emotional needs and to assess organizational readiness in appreciating increased work effort, employes form beliefs about the company's positive or negative orientation toward them (Eisenberger, Stinglhamber, Vandengerghe, Sucharski, \& Rhoades, 2002). This theory suggests that employes who perceive that they are receiving more support from the organization will develop a positive attitude toward the organization (Eisenberger et al., 1986), increasing their desire to remain part of the organization (Husain \& Asif, 2012). The process is based on a reciprocity principle that generates the employe's sense of duty to support the organization through the fulfillment of the socio-emotional needs that build an employe's identity as part of the organization, and through the forming of the belief that every effort will be rewarded by the organization (Rhoades and Eisenberger, 2002). This sense of duty, self-identity as part of the organization, and the belief that their efforts will surely be rewarded all contribute to increasing the employe desire to remain part of the organization. Thus, POS affects employe intentions to stay or leave the organization. Based on this, the first hypothesis in this research is as follows:

H1a: There is an influence of POS on TI in PT X Operational OP's employes.

Efforts to improve POS can be made by improving any of the three aspects of POS organizational support: these are fairness, support from supervisors, and organizational rewards (Eisenberger et al., 1986). PT X already has a well-built system of reward and promotion. Every agent is debriefed with valid standards and is constantly monitored through a standardized performance evaluation system. This system is the base for rewards provided in the form of incentives and additional awards. Along with the results of performance evaluation, awards also become one of the considerations in employe selection for talent programs and promotions. Employees are also provided with the opportunity to receive additional training to increase and improve their performance. This makes it equally possible for all PT X employes to improve their careers. Therefore, the fairness and organizational rewards aspects were already being conducted appropriately at PT X. Meanwhile, there has been no effort to improve the organizational support available through their supervisors. Supervisors are agents of the 
organization (Eisenberger et al., 2002), and employes view their actions as organizational acts (Eisenberger, 1986). Therefore, employes perceive support from their supervisors as organizational support (Eisenberger et al., 2002). Thus, interventions to improve POS in PT X's employes can be accomplished by increasing supervisor support.

Increasing supervisor support can be accomplished through optimal implementation of coaching by supervisors. Efforts to manage employes that include coaching will fulfill employe needs in the socio-emotional arena (Eisenberger et al., 1997; Rhoades \& Eisenberger, 2002), just like increased POS will increase employe needs in the socio-emotional arena. This is because coaching implementation is a form of organizational support. By nature, coaching is conducted by developing a relationship (Bachikrova et al., 2010) through collaborative and supportive interaction (Grant, 2017; Wolfe in Gallacher, 1997) between coaches (supervisors) and coachees (subordinates). Thus, coaching by supervisors can be regarded as one representation of POS (Woo, 2017). Moreover, Bresser and Wilson (2010) said that one of the benefits of coaching is to improve employe retention, so coaching optimization aligns with addressing the turnover problem at PT X.

Coaching can be described as a process in which the coach creates a relationship that helps the coachee learn, resulting in improved performance as a byproduct of the relationship (Mink, Owen, \& Mink, as cited in Ellinger, Beattie, \& Hamlin, 2010). More specifically, Grant (2017) defined coaching as a collaborative and action-oriented conversation conducted to facilitate experience, goal achievement, self-directed learning, and to improve the coachee's performance in both work and other aspects. The implementation of coaching interventions in this research are based on a solution-focus coaching (SF coaching) approach that prioritizes solution formulation rather than problem-solving. The principles underlying the solution-focus coaching approach (Cavanagh \& Grant, 2010, Grant, 2011) are (1) non-pathological orientation; (2) future oriented; (3) focused on solutions instead of problems; (4) focused on the articulation of specific and clear results or goals; (5) oriented toward action steps that focus on changing what does not work; and (6) the activation of the coachee's resources.

This approach is chosen because SF coaching emphasizes the shifting of focus from problem to solution (Cavanagh \& Grant, 2010; Grant, 2011) so as to better facilitate supervisors in separating coaching from the evaluation process and to optimize the benefits of coaching (Wolfe in Gallacher, 1997). The second reason is due to the SF approach's principles that emphasize the activation of coachee resources so that the solution comes from the coachee (Cavanagh \& Grant, 2010; Grant, 2011). The solution will then be used as the coachee's (employe's) goal, and the role of coach is to support the coachee in achieving that goal. Thus, the SF coaching itself serves as a form of supervisor support for subordinates' achieving their goals. The last reason is that SF coaching is the most appropriate approach for workplace characteristics that emphasize the merging of the coaching process into everyday activities (Grant, 2017). One SF coaching principle is to be action-oriented using small steps to progress toward the goal (Grant, 2011). Thus, the coaching process focuses on the implementation of small actions that can be achieved in the short-term (Cavanagh \& Grant, 2010). Unlike directly achieving the main goal all at once, achieving a goal through small actions can be followed using shorter coaching sessions and by merging the coaching process into daily activities. This aligns with the coaching at work characteristic in which the execution of coaching is fuzed within everyday processes (Ellinger et al., 2010). Thus, the SF approach will promote an optimal implementation of coaching by 
supervisors. Based on this, the second hypothesis in this study is:

H1b: There is an increase of coaching knowledge after the implementation of coaching optimization interventions on participating Operational OP employes at PT X.

\section{Methods}

\section{Participants}

Research participants involved in testing the first hypothesis were 164 employes taken using a stratified random sampling method based on the project unit. These employes all have the characteristics of Operational OP employes at PT X who have passed training and probation periods. The majority of participants consisted of females $(64.3 \%)$, Y generation (17 - 36 years) (98.8\%), S1-level educated $(44.3 \%)$, less than one year of tenure $(61 \%)$, and on staff $(86.7 \%)$. The intervention participants for the second hypothesis testing initially totaled 12 people (purposive sampling method). Criteria for these participants were team leader and supervisor level in the Operational OP department who were involved in the retrieval of data for testing the first hypothesis. Company policies (with respect to time and permission from clients) restricted intervention participants to eight. All who participated in the intervention were $\mathrm{Y}$ generation. The majority of them were female (63.4\%), S1-level educated (75\%), and had between two to three years of tenure $(37.5 \%)$, while the levels were equally divided between four team leaders and four supervisors.

\section{Research Design}

This research used a correlation research design to test the first hypothesis and a before-and-after study research design to test the second hypothesis.

\section{Measures}

Both TI and POS measurement tools were adapted into the Indonesian language and initially tested with 72 respondents. TI was measured using a three-item TI questionnaire used in a study by Lindbolm et al. (2015), with a Likert scale ranging from 1 to 6 . The test yielded a reliability coefficient value of 0.823 and corrected item-total correlation above 0.2 on all items. POS was measured using a ten-item short version POS survey used in a recent study published by Neves and Eisenberger in 2014. The survey had a 6-point Likert scale that consisted of six favorable items and four unfavorable items. The test yielded a reliability coefficient value of 0.854 and a corrected item-total correlation value above 0.2 , except for item number 3 . The learning evaluation was measured using five multiple choice items consisting of four multiple choice questions and one open-ended question. Scoring for multiple choice items used dichotomy (1 and 0 ), while scoring for the open-ended question ranged from 0 to 3 . A score of 3 is for a correct response (answers are solution-focused questions); 0 is for no response; 1 is for an incorrect response (answers are problem-focused questions); and 2 is for an inappropriate response (answers are not focused on solutions or problems).

\section{Procedure}

The author first made contact with PT X's management to acquire permission for collecting data from their employes. Before testing the first hypothesis, a preliminary data collection using focus group discussion (FGD) and interviews was conducted to ascertain whether POS was a possible antecedent of TI. FGD was conducted in two stages on a total of eight agent-level employes 
representing each project in Operational OP, while the team leaders were interviewed individually. The result of the data collection suggested some unfulfilled expectations among PT X's employes, causing them to perceive their company as being less supportive of its employes' needs and interests. Therefore, POS was confirmed as a possible antecedent of employe TI at PT $\mathrm{X}$.

Data collection for TI and POS was conducted using hard-copy questionnaire forms distributed in envelopes. Each respondent was given approximately a week to return the completed questionnaire in a sealed envelope. The author also conducted interviews with the PT X Learning and Development Manager and Operational OP Manager in order to learn about the nature and obstacles of coaching practices by superiors at PT X. Among the most apparent obstacles that deters participants from an optimal practice of coaching are time constraints, negative perception of coaching by subordinates, and the misuse of coaching as a means of evaluation. The results of these interviews were then used as one of the considerations in the development of a coaching optimization intervention program.

The coaching optimization intervention program consists of four stages. The first stage is Coaching Briefing, the second is Documented Coaching, the third is Coaching Feedback, and the fourth is Performance-Based Rewards. Coaching Debriefing is implemented only once in the beginning of the implementation program. The purpose of this stage is to develop participant understanding of what optimal coaching means; also, to increase participant comprehension on the use of the SF approach to increase the benefits of coaching practice and decrease coaching obstacles. Participants received a coaching action plan and customized question materials, to be used in the next stage.

Table 1

Stages of Coaching Optimization Program

\begin{tabular}{|c|c|c|c|c|}
\hline \multicolumn{2}{|c|}{ Stages } & \multirow{2}{*}{$\begin{array}{l}\text { Execution } \\
\text { Time } \\
\text { At the } \\
\text { beginning } \\
\text { (once) }\end{array}$} & \multirow{2}{*}{$\begin{array}{l}\text { Expected Outcome } \\
\text { (1) Participants understand the benefits, } \\
\text { principals, and process of optimal } \\
\text { coaching, (2) Action plans and question } \\
\text { materials }\end{array}$} & \multirow{2}{*}{$\begin{array}{l}\text { Procedures } \\
\text { Workshop coaching "reach more with } \\
\text { coaching" }\end{array}$} \\
\hline 1 & $\begin{array}{l}\text { Coaching } \\
\text { Briefing }\end{array}$ & & & \\
\hline 2 & $\begin{array}{l}\text { Documented } \\
\text { Coaching }\end{array}$ & $\begin{array}{l}\text { Eight weeks } \\
\text { in each cycle }\end{array}$ & $\begin{array}{l}\text { Participants conduct coaching according } \\
\text { to their action plans }\end{array}$ & $\begin{array}{l}\text { Implementation of coaching, documenting } \\
\text { coaching executions, completing feedback } \\
\text { forms by coachee }\end{array}$ \\
\hline 3 & $\begin{array}{l}\text { Coaching } \\
\text { Feedback }\end{array}$ & $\begin{array}{l}\text { At the end of } \\
\text { each cycle }\end{array}$ & $\begin{array}{l}\text { Participants receive feedback regarding } \\
\text { their coaching implementations }\end{array}$ & $\begin{array}{l}\text { Coaching performance appraisal by } \\
\text { supervisors, based on the reports of coaching } \\
\text { implementations and feedback from coachee } \\
\text { coaching feedback by superiors }\end{array}$ \\
\hline 4 & $\begin{array}{l}\text { Coaching } \\
\text { Awards }\end{array}$ & $\begin{array}{l}\text { At the end of } \\
\text { each cycle }\end{array}$ & $\begin{array}{l}\text { Strengthening participants newly } \\
\text { learned coaching practice }\end{array}$ & $\begin{array}{l}\text { Most effective coach (tefco awards) for the } \\
\text { highest learning result and highest } \\
\text { development coach (telco awards) for the } \\
\text { highest improvement in learning result }\end{array}$ \\
\hline
\end{tabular}

The second, third and fourth stages are carried out in six cycles (lasting two months for each cycle) over one year. The purpose of Documented Coaching is to apply SF coaching to participant's subordinates, using the first stage's outputs as guidelines (coaching action plan and customized question materials). The physical outputs of the second stage include feedback forms 
completed by the participant's subordinates and a coaching notebook written by participants. The purpose of Coaching Feedback is to discuss and evaluate the participant's coaching execution based on the previous stage's outputs. The output of the third stage is coaching implementation feedback received by the participants and a coaching performance appraisal conducted by the participant's superiors. The purpose of Coaching Awards is to reinforce the implementation of more optimal coaching practices among the participants, based on the output of the previous stage (coaching performance appraisal).

Due to time constraints and a lack of permission from the company, this study was only able to implement the first stage of the coaching optimization program. Furthermore, the first stage was conducted in two separate batches in order to accommodate all eight participant schedules. In order to comply with the minimum quota of the debriefing class, additional non-target attendees were added to participate in both Coaching Debriefing batches. These non-target attendees consisted of team leaders and supervisors from departments other than Operational OP.

Table 2

The First Stage - Coaching Briefing Sessions

\begin{tabular}{|c|c|c|}
\hline Session & Methods & Procedures/ Materials \\
\hline \multirow[t]{5}{*}{$\begin{array}{l}\text { Be a Good Leader, Be a } \\
\text { Coach }\end{array}$} & 1. Interactive Discussion & $\begin{array}{l}\text { Discussion topics: (1) definition of coaching, (2) the purpose } \\
\text { of coaching, (3) obstacles in coaching }\end{array}$ \\
\hline & $\begin{array}{l}\text { 2. Blind Drawing Game } \\
\text { (customized) }\end{array}$ & $\begin{array}{l}\text { Participants are put in pairs as a drawer and a coach: in the } \\
\text { first stage, the drawer will draw what is instructed by the } \\
\text { coach; in the second stage, the drawer is given options to } \\
\text { choose a key and allowed to ask for confirmation regarding } \\
\text { the coach's instructions. }\end{array}$ \\
\hline & 3. Simulation Debrief & Debrief questions: which stage is easier and why? \\
\hline & $\begin{array}{l}\text { 4. Material: Coaching Principals } \\
\text { and Functions }\end{array}$ & $\begin{array}{l}\text { The function of coaching is to give support and to manage } \\
\text { the relationship, instead of to evaluate }\end{array}$ \\
\hline & 5. Action Planning 1 & $\begin{array}{l}\text { Participants describe the conditions of optimal coaching } \\
\text { (number } 10 \text { out of a 10-point scale), noting current } \\
\text { conditions, and describe the condition of the nearest target }\end{array}$ \\
\hline \multirow[t]{5}{*}{$\begin{array}{l}\text { Let's Coach, Let's Ask } \\
\text { Questions }\end{array}$} & 1. Questioning simulations & $\begin{array}{l}\text { Participants are grouped into coach A (solution-focused } \\
\text { questions), coach B (problem-focused questions), coachee, } \\
\text { and observer; coachee and observer will not be informed of } \\
\text { the difference between coach A and B }\end{array}$ \\
\hline & 2. Simulation Debrief & $\begin{array}{l}\text { Debrief question: which is more comfortable and effective, } \\
\text { coach A or B? }\end{array}$ \\
\hline & $\begin{array}{l}\text { 3. Material: Coaching } \\
\text { Questioning Methods }\end{array}$ & $\begin{array}{l}\text { Exemplary solution-focus and problem-focus questions, } \\
\text { coaching implementation stages }\end{array}$ \\
\hline & 4. Make Your Own Questions & $\begin{array}{l}\text { Participants develop their own questions that they can use for } \\
\text { each coaching stage }\end{array}$ \\
\hline & 5. Action Planning 2 & $\begin{array}{l}\text { Participants develop action plans based on the result of the } \\
\text { second learning session }\end{array}$ \\
\hline
\end{tabular}

Implementation of the coaching briefing was conducted on May 31, 2017 for the first batch and on June 2, 2017 for the second batch, at a training room designed for 20 persons arranged in a semi-circle layout. Batches were attended by 16 and 13 participants, respectively.

\section{Data Analysis}

This study used descriptive statistical methods to simplify and organize raw data in order for it to be easily understood. This study also used Pearson correlation and regression to analyze the 
relationship between the two variables. Finally, this study used a Wilcoxon signed rank test to test the significance of the difference between test scores before and after the intervention's implementation.

\section{Results}

A correlation test between TI and POS yields a coefficient of correlation at.52, significant at the. 01 level. This shows that there is a significant negative relationship between TI variables and perceived organizational support in this study. The result of calculation of influence analysis from POS to TI suggests a significant negative influence $(p=.00)$ from POS to TI, where $26.6 \%$ variance of TI can be explained by POS. Thus, hypothesis 1a is supported; there is a significant negative influence of POS on TI at PT X Operational OP employes. Reaction evaluation yields a score above three (on a 5-point Likert scale) for each aspect with the lowest reaction evaluation result on the facilitator aspect and implementation with an average score of 3.88 .

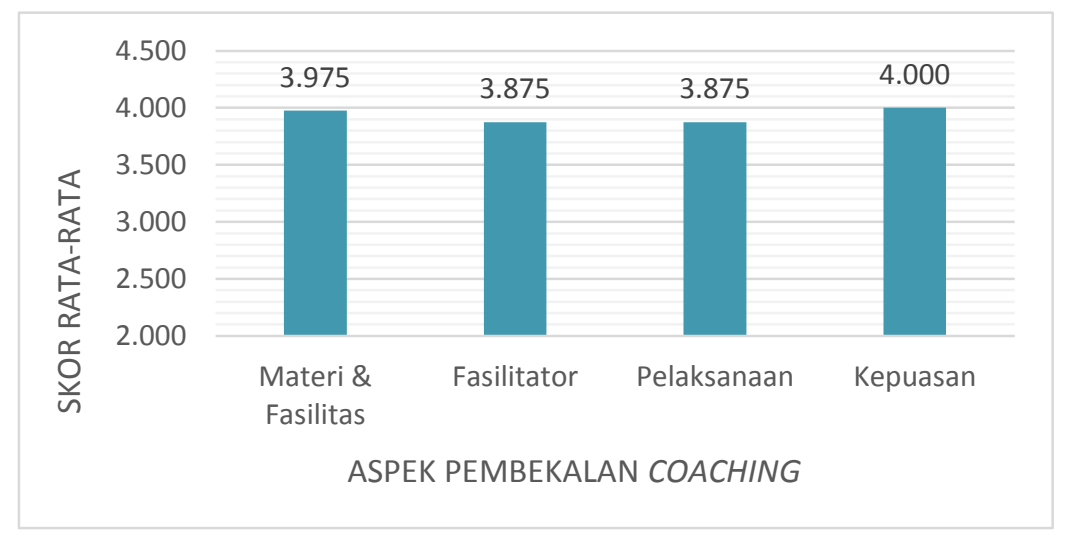

Figure 1. Reaction Evaluations

The measurement of learning evaluation resulted in the conclusion that there are participants who experienced a decrease in scores, and almost all had increased scores (ranging from 1 to 4 points of increase), except the seventh participant, who scored equally on pretest and posttest.

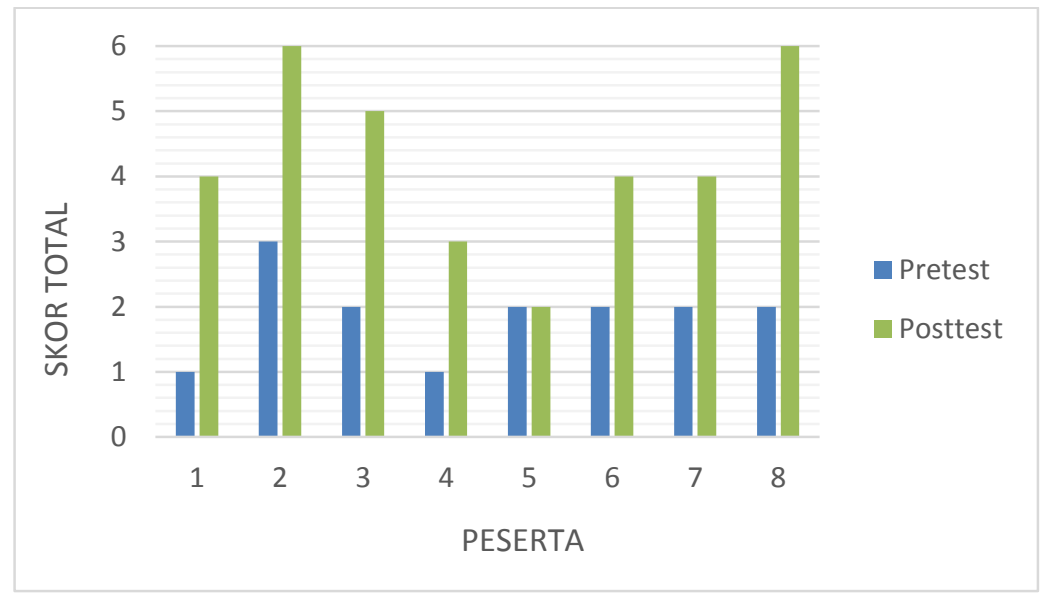

Figure 2. Learning Evaluations 
The Wilcoxon Signed Rank Test showed a significant difference between pretest score and posttest score with $p=0.016$. Descriptive test results yielded a mean value of 1.88 on a pretest score and a mean value of 4.25 on a post-test score. Hence, hypothesis $1 \mathrm{~b}$ is supported; there is an increase of coaching knowledge after the implementation of coaching optimization interventions on participating Operational OP employes at PT X.

\section{Discussion}

Results of this study showed a significant negative influence of POS on TI of Operational OP employes at PT X, supporting hypothesis 1a. There is a $26.6 \%$ variance in employe TI at Operational OP at PT X that can be explained by POS. Thus, an effort to increase POS will decrease TI. This result aligns with the results of previous studies (Eisenberger et al., 2002; Husain \& Asif, 2012; Kalidass \& Bahron, 2015; Rhoades \& Eisenberger, 2002) that found an influence of POS on TI. Moreover, it also supports the norm of reciprocity that states that organizational intentions perceived by employes will determine employe attitudes toward the organization (Levinson, 1965). This norm of reciprocity is the fundamental principle of organizational support theory (Eisenberger et al., 1986); thus, the result of this study strengthens the idea that managing employe outcomes (including turnover) can be done by carefully managing employe POS.

However, the influence of POS on TI only reached 26.6\%, indicating that there are other factors that can explain TI in the OP operational employes at PT X. There are two other major predictors of TI found in the meta-analytical study conducted by Wong et al. (2015); namely, job insecurity and organizational commitment. At PT X, the status of agent-level employes is contract instead of permanent. Unlike permanent employes, the result of contracted employee performance evaluations is embedded with additional risk regarding the continuation or termination of their employment. Therefore, their job security is generally lower than is found in permanent employes. This indicates the possibility of job insecurity problem among agent-level employes at PT X that may be a possible contribution to TI.

Another possible factor is organizational commitment, which according to some studies might have a role in the relationship between POS and TI (Islam et al., 2013, Rhoades, Eisenberger, \& Armeli, 2001). According to the norm of reciprocity, POS generates an employe's sense of duty to support the organization (Rhoades \& Eisenberger, 2002) and increases employes' desire to remain part of the organization (Husain \& Asif, 2012). This aligns with the concept of normative organizational commitment, which represents the sense of obligation to remain part of the organization (Allen \& Mayer, 1990). Based on this idea, employe perception that the organization supports them (POS) generates a sense of duty to remain part of the organization (normative organizational commitment), thus decreasing employe intentions to leave the organization (TI). That being said, the author encourages a measurement of job insecurity as an additional independent variable as well as organizational commitment as a mediator in future TI research. 
Reaction evaluation for stage one intervention implementation indicates that all participants of the intervention were satisfied with all aspects of the Coaching Briefing, including materials and facility, facilitator, implementation, and overall satisfaction. This indicates that the preparation, planning, and implementation of the Coaching Briefing were conducted well enough to meet participants' expectations. The author has collected additional qualitative data regarding the nature of coaching conducted at PT X, the characteristics of participants, their attitudes toward coaching, and the problems they experienced with the implementation of coaching. The intervention programs were developed in consideration of the results of the data collection so that it could be customized to their needs. Aside from equipping the participants with knowledge important to optimizing their coaching implementation, the Coaching Briefing especially highlights the participants' needs and offers solutions to their current problems. This is done so that the intervention program will not only benefit the organization as a whole, but the participants will also personally benefit from it.

Among the four aspects measured in reaction evaluation, facilitator and implementation aspects have the lowest score. This might be related to the shortening of the implementation's time, which also made the facilitator somewhat rushed in delivering the materials. All targeted participants were required to first obtain permission from each client on each project unit because their working time is strictly monitored, measured, and reported to clients every several hours. These valuable working times mean a great deal to both PT X's and their client's performance, so it was difficult to receive permission for participants to attend the Coaching Briefing. Therefore, the duration of the Coaching Briefing implementation, which was initially about two to three hours, had to be shortened to only one hour. Hence, both the implementation and facilitator aspects ended up with the lowest scores. Learning evaluation shows that a learning effect is present where participants have increased knowledge related to the material presented in the Coaching Briefing, thus supporting hypothesis 1b. All participants have increased knowledge except the seventh participant with the unchanging score. Throughout the implementation, this participant seemed to be attempting to pay attention but had to use the phone and leave the room to receive calls. He expressed that there was an urgent issue in his work and apologized to the facilitator. The existence of urgent problems in his work probably inhibited his learning.

In this research, the time constraints and permission problems also resulted in only the first stage of the intervention implementation being completed. This study also did not conduct an evaluation on behavioral level, and it had no control group. One reason for this was the delay in intervention implementation time due to obstacles in obtaining permits and schedule agreements, including permission to borrow working time from another group of employes to satisfy the learning evaluation form for control. For optimal results, further research should include a control group, measure behavioral level evaluation after one cycle of interventions (including stages two, three, and four), and ensuring the commitment of all parties involved in the research to avoid time, permission, or other work-related constraints.

\section{References}

A. T. Kearney. (2016). On the eve of disruption, 2016 A. T. Kearney Global Services Location Index. Retrieved from https://www.atkearney.com/strategic-it/global-services-location-index/full-report 
Allen, N. J., \& Meyer, J. P. (1990). The measurement and antedecents of affective, continuance, and normative commitment to the organization. Journal of Occupational Psychology, 63, 1-18.

Bresser, F., \& Wilson, C. (2010). What is coaching? In J. Passmore. (Eds.), Excellence in coaching: The industry guide (2nd ed.) (pp. 9-26). London: KoganPage.

BUMN harus mampu beradaptasi dengan dunia digital. (2017, Januari 26). Indotelko: Indepth. Retrieved from http://www.indotelko.com/kanal?c=id\&it=bumn-harus-dunia-digital.

Cavanagh, M. J., \& Grant, A. M. (2010). The solution focused approached to coaching. In E. Cox, T. Bachikrova, \& Clutterbuck, D. (Eds.), The complete handbook of coaching (pp. 55-67). London: Sage Publications.

Demirbag, M., Mellahi, K., Sahadev, S., \& Elliston, J. (2012). Employee service abandonment in offshore operations: A case study of a US multinational in India. Journal of World Business, 47, 178-185. doi: 10.1016/j.jwb.2011.04.004.

Ellinger, A. D., Beattie, R. S., \& Hamlin, R. G. (2010). The manager as coach. In E. Cox, T. Bachikrova, \& Clutterbuck, D (Eds.), The complete handbook of coaching (pp. 257-270). London: Sage Publications.

Ellis, V., \& Taylor, P. (2006). You don't know what you've got till its gone: re-contextualising the origins, development, and impact of the call center. New Technology, Work, and Employment, 21(2), 107-122. doi: 10.1111/j.1468005X.2006.00167.

Eisenberger, R., Huntington, R., Hutchison, S., \& Sowa, D. (1986). Perceived organizational support. Journal of Applied Psychology 71(3), 500-507. doi: 0021-9010/86/500/\$00.05.

Eisenberger, R., Stinglhamber, F., Vandengerghe, C. Sucharski, I. L., \& Rhoades, L. (2002). Perceived supervisory support: Contribution to perceived organizational support and employe retention. Journal of Applied Psychology 87(3), 565573. doi: 0.1037//0021-9010.87.3.565.

Future of work. (2012). Business process services: Redefining business process outsourcing. London: Cognizant.

Gallacher, K. (1997). Supervision, mentoring, and coaching: Methods for supporting personnel development. In Winton, P. J. McCollum, J. A., \& Catlett, C. (Eds.), Reforming personnel preparation in early intervention: Issues, model, and practical strategies (pp. 191-214). Baltimore: Paul H. Brooks Publishing.

Gosh, P., Satyawadi, R., Joshi, J. P., \& Shadman, M. (2013). Who stays with you? Factor predicting employe's turnover. Internasional Journal of Organizational Analysis, 21(3), 288-312. doi: 10.1108/IJOA-Sep-2011-0511.

Grant, A. M. (2011). The solution-focused inventory: A tripartite taxonomy for teaching, measuring and conceptualizing a solution-focused approach to coaching. The Coaching Psychologist, 7(2), 1748-1104.

Grant, A. M. (2017). The third generation of workplace coaching: Creating a culture of quality conversations. Coaching: An International Journal of Theory, Research, and Practice, 10(1), 37-53. doi: 10.1080/17521882.2016.1266005.

Griffeth, R. W., Hom, P. W., \& Gaertner, S. (2000). A meta-analysis of antecedents and correlates of employe turnover: update, moderator tests, and research implications for the next millenium. Journal of Management, 26(3), 263-468.

Holtom, B. C., Mitchell, T. R., Lee, T. W., \& Eberly, M. B. (2008). Turnover and retention research: A glance at the past, a closer review of the present, and a venture into the future. The Academy of Management Annuals 2(1), 231-274. doi: $10.1080 / 19416520802211552$.

Husain, T. \& Asif, S. (2012). Is employe turnover intention driven by organizational commitment and perceived organizational support? Journal of Quality and Technology Management, 8(2), 1-10.

Hwang, J. I., \& Chang, H. (2009). Work climate perception and turnover intention among Korean hospital staff. International nursing review, 56, 73-80.

Islam, T., Khan, S. R., Ahmad, U. N., Ali, G., Ahmed, I., \& Bowra, Z. A. (2013). Turnover intentions: The influence of perceived organizational support and organizational commitment. Procedia Social and Behavioral Science 103, 12381242. doi: 0.1016/j.sbspro.2013.10.452.

Irfandi, Edo. (2013). Indonesia companies needs to capitalize on improving employe engagement trends. Retrived from http://www.aon.com/apac/human-resources/thought-leadership/asia-connect/2014-vol7-issue5/indonesia-companies-tocapitalize-on-improving-employe-engagement.jsp

Jacobs, C., \& Roodt, G. (2011). A human capital predictive model for agent performance in contact centers. Journal of Industrial Psychology, 37(1), 940-959. doi:10.4102/sajip.v37i1.940.

Johnston, N., \& Spinks, W. (2013). Organizational climate and employe turnover intention within a franchise system. Journal of New Business Ideas and Trends 11(1), 20-41.

Joseph, D., Ng, K., Koh., C., \& Ang, S. (2006). Turnover of information technology professionals: A narrative review, metaanalytic structural, equation modeling, and model development. MIS Quarterly, 31(3), 547-577.

Kalidass, A. \& Baron, A. (2015). The relationship between perceived supervisory support, perceived organizational support, organizational commitment, and employe turnover intention. International Journal of Business Administration, 6(5), 82-89. doi: 0.5430/ijba.v6n5p82.

Kaur, B., Mohindru, \& Pankaj. (2013). Antecedents of turnover intention: A literature review. Global Journal of Management and Business Studies, 3(10), 1219-1230.

Levinson, H. (1965). Reciprocation: The relationship between man and organization. Administrative Science Quarterly, 9(4), 370-390. doi: 10.2307/2391032.

Lindblom, A., Kajalo S., \& Mitronen L. (2015). Exploring the links between ethical leadership, customer orientation, and employe outcomes in the context of retailing. Management Decision 53(7), 1642-1658. doi: 10.1108/MD-04-20150126. 
Neves, P., \& Eisenberger, R. (2014). Perceived organizational support and risk-taking. Journal of Managerial Psychology, 29(2), 187-205. doi: 10.1108/JMP-07-2011-0021.

Park, T. \& Shaw, J. D. (2013). Turnover rates and organizational performance: Ameta-analysis. Journal of Applied Psychology, 98(2), 268-309. doi: 10.1037/a0030723.

Priambada, K., Maharta, A. E., Maryono, \& Kusumanto, R. (2008). Outsourcingversus serikat pekerja?: An introduction to outsourcing. Jakarta: Alihdaya pub.

Research and Markets. (2016). Indonesia ontact enter and CRM market forecast: 2016-2021. Asia Pacific Research Group.

Rhoades, L. \& Eisenberger, R. (2002). Perceived Organizational Support: A review of the literature. Journal of Applied Psychology, 87(4), 698-714. doi: 0.1037//0021-9010.87.4.698.

Rhoades, L., Eisenberger, R. and Armeli, S. (2001). Affective commitment to the organization: The contribution of perceived organizational support. Journal of Applied Psychology, 86(5), 825-836. doi: 10.1037//0021-9010.87.3.565.

Rozaini, R., Norailis, A. W., \& Aida, B. (2015). Roles of organizational support in quality of work life in insurance industry. Journal of Economics, Business, and Management, 3(8), 753-757. doi: 10.7763/JOEBM.2015.V3.280.

Saleh, R., Nair, M. S., \& Harun, H. (2012). Job satisfaction, organizational commitment, and turnover intention: A case study on employes of a retail company in Malaysia. International Journal of Social, Behavioral, Educational, Economic, Business, and Industrial Engineering, 6(12), 3429-3436

Tett, R. P., \& Meyer, J. P. (1993). Job satisfaction, organizational commitment, turnover intention, and turnover: Path analysis based on meta-analytics findings. Personnel Psychology, 46, 256-293.

Umer, M., \& Naseem, M. A. (2011). Employees retention (human capital) in business process outsourcing (BPO) industry in Pakistan. Global Journal of Management and Business Research, 11(3), 90-97.

Wong, Y., Wong, Y., dan Wong, C. (2015). An integrative model of turnover intention: Antecedents and their effects on employe performance in Chinese joint ventures. Journal of Chinese Human Resource Management 6(1), 71-90. doi: 10.1108/JCHRM-06-2014-0015.

Woo, H. R. (2017). Exploratory study examining the joint impacts of mentoring and managerial coaching on organizational commitment, Sustainability, 9(181), 1-15.

Yamazakia, Y., \& Petchdee, S. (2015). Turnover intention, organizational commitment, and specific job satisfaction among production employes in Thailand. Journal of Business and Management, 4(4), 22-38. doi: 10.12735/jbm.v4i4p22. 